УДК 330.341 .1

Зайченко В.В., к.н.держ.упр., доцент

Центральноукраїнський національний технічний університет

\title{
АНАЛІЗУВАННЯ ДЕРЖАВНОЇ ПОЛІТИКИ ЗАБЕЗПЕЧЕННЯ ТЕХНОЛОГІЧНОЇ КОНКУРЕНТОСПРОМОЖНОСТІ ЕКОНОМІКИ УКРАЇНИ
}

У статті розглянуто питання актуальності забезпечення технологічної конкурентоспроможності економіки в умовах сучасних глобальних викликів і загроз та тенденції до посилення глобальної конкуренції. Вказано на важливість формування в країні інституційно-організаційної та інституційноправової систем державної політики забезпечення інноваційно-технологічної діяльності та розвитку. Надано розгорнуту характеристику вітчизняної інституційно-організаційної системи державної політики забезпечення технологічної конкурентоспроможності економіки. Розкрито вітчизняну інституційноправову систему державної політики забезпечення технологічної конкурентоспроможності економіки. Наведено результати аналізу ефективності державної політики забезпечення технологічної конкурентоспроможності економіки України за функціями управління.

Ключові слова: технологічна конкурентоспроможність економіки, державна політика забезпечення, інституційно-правова та інституційно-організаційна компоненти.

Zaychenko V.

\section{THE STATE POLICY OF UKRAINE'S ECONOMY TECHNOLOGICAL COMPETITIVENESS PROVIDING ANALYSIS}

The article deals with the relevance of ensuring the technological competitiveness of the economy in the context of the current global challenges and threats and the tendency to increase global competition. The importance of forming in the country of institutional, organizational and institutional-legal systems of the state policy of ensuring innovation-technological activity and development is pointed out. The expanded description of the domestic institutional and organizational system of state policy providing technological competitiveness of the economy is given. The domestic institutional and legal system of the state policy of ensuring the technological competitiveness of the economy is revealed. The results of the analysis of the effectiveness of the state policy of ensuring the technological competitiveness of the Ukrainian economy by management functions are presented.

Key words: technological competitiveness of economy, state policy of providing, institutional and legal and institutional and organizational components.

Зайченко В. В.

\section{АНАЛИЗ ГОСУДАРСТВЕННОЙ ПОЛИТИКИ ОБЕСПЕЧЕНИЯ ТЕХНОЛОГИЧЕСКОЙ КОНКУРЕНТОСПОСОБНОСТИ ЭКОНОМИКИ УКРАИНЫ}

В статье рассмотрены вопросы актуальности обеспечения технологической конкурентоспособности экономики в условиях современных глобальных вызовов и угроз и тенденции к усилению глобальной конкуренции. Указано на важность формирования в стране институциональноорганизационной и институционально-правовой систем государственной политики обеспечения инновационно-технологической деятельности и развития. Предоставлено развернутую характеристику отечественной институционально-организационной системы государственной политики обеспечения технологической конкурентоспособности экономики. Раскрыто отечественную институциональноправовую систему государственной политики обеспечения технологической конкурентоспособности экономики. Приведены результаты анализа эффективности государственной политики обеспечения технологической конкурентоспособности экономики Украины по функциям управления.

Ключевые слова: технологическая конкурентоспособность экономики, государственная политика обеспечения, институционально-правовая и институционально-организационная составляющие. 
Постановка проблеми у загальному вигляді i iï зв'язок 3 важливими науковими та практичними завданнями. Наявні в Україні недоліки стану та тенденцій інноваційно-технологічної діяльності, забезпечення технологічної конкурентоспроможності економіки України, беззаперечно, у значній мірі обумовлені низкою і об'єктивних і суб' єктивних, внутрішніх та зовнішніх причин та чинників. Тут і нестабільність економіко-правового та політичного середовища, і загальний стан економіки, конкурентного середовища та внутрішнього ринку, і нерозвиненість та низький рівень спроможності суб'єктів інфраструктури інноваційної та науководослідної діяльності, і низька активність суб'єктів бізнесу зі створення і впровадження нових сучасних технологій, i слабкість фінансово-інвестиційної інфраструктури підтримки інноваційно-технологічної діяльності. Перелік чинників можна продовжувати, але слід визнати, що в значній мірі первісною такого стану справ слугує недостатньо ефективна, якісна, виважена і керована державна політика в аналізованій сфері. За будь-яких можливостей та ресурсного забезпечення держава, орієнтована на зміцнення конкурентоспроможності національного господарства і покращення місця економіки в системі міжнародного поділу праці, має вести більш виважену, чітко сплановану державну інноваційно-технологічну політику.

Аналіз останніх досліджень, у яких започатковано вирішення проблеми. Загальні умови та засади державної політики формування технологічної конкурентоспроможності економіки достатньо глибоко вивчені у працях В. Геєця [3], Л. Піддубної [4], Л. Федулової [6], 3. Юринець [8] та ін. Разом із тим, сучасні тенденції та умови, нові виклики, ризики та загрози формують специфічне середовище інноваційнотехнологічної діяльності, а також засади конкуренції, які потребують постійного врахування в рамках більш якісної та ефективної державної політики забезпечення технологічної конкурентоспроможності національного господарства.

Цілі статті. Метою статті є аналіз інституційно-організаційного та інституційноправового складових державної політики забезпечення технологічної

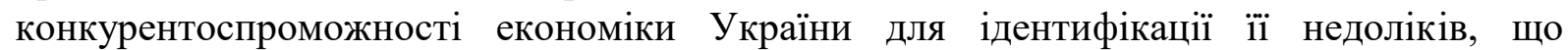
потребують усунення.

Виклад основного матеріалу дослідження 3 повним обгрунтуванням отриманих наукових результатів. Достатні передумови для формування технологічної конкурентоспроможності економіки України все ще залишаються наявними. Як мінімум двома аргументами на користь такого висновку слугують наступні. По-перше, це сформованість в країні інституційно-організаційної системи державної політики забезпечення інноваційно-технологічної діяльності та розвитку.

По-друге, це сформованість в країні інституційно-правової системи державної політики в аналізованій сфері. Йдеться про те, що за період незалежності України було прийнято (змінено, удосконалено) низку кодексів, законів, постанов Верховної Ради України та Кабінету Міністрів України, указів Президента України, відомчих нормативно правових актів. Якщо не безпосередньо, то опосередковано чи частково вони стосувалися планування і регулювання розвитку інноваційно-технологічної діяльності, у тому числі орієнтованої на забезпечення конкурентоспроможності національної економіки.

Відносно першої компоненти, політику підготовки фахівців та кваліфікованих кадрів для науково-дослідної і інноваційно-технологічної діяльності, розвитку освіти і науки безпосередньо реалізує Міністерство освіти і науки України. Частково його політика ефективна і дозволяє формувати достатньо якісне інтелектуально-кадрове 
забезпечення для подальшої діяльності в сфері забезпечення технологічної конкурентоспроможності національного господарства. Позитивно, що міністерство забезпечило збереження й інфраструктурного потенціалу вітчизняної науково-дослідної та інноваційної діяльності, представленої чисельними організаціями та іншими структурами, результатами їх досліджень, що визнаються провідними в світі.

Але наявні й недоліки. Особливо слід вести мову про недостатній рівень науки у ВН3, зокрема іiі прикладного характеру, незорієнтованості на тісну співпрацю 3 представниками бізнесу, слабкий внесок у створення об'єктів інтелектуальної власності (передусім - об'єктів промислової власності), які в подальшому були б впроваджені у реальному секторі національної економіки, обмежений вплив на розбудову інфраструктури співпраці освіти, науки і інноваційного бізнесу.

Комплексний вплив державного регулювання на функціонування i розвиток вітчизняної інноваційно-технологічної системи з подальшим внеском у формування технологічної конкурентоспроможності економіки у найбільшій мірі $\epsilon$ вотчиною Міністерства економічного розвитку і торгівлі України. По-перше, міністерство формує державну економічну політику в цілому; по-друге, в його складі є одразу декілька структурних підрозділів, які мають відношення до розвитку інноваційної та технологічної діяльності, інтелектуальної власності, сфери інвестування та фінансової підтримки і т. д.; по-третє, міністерство курує діяльність значної чисельності державних підприємств, а, відтак, і є дотичним до впровадження стратегій їх функціонування та розвитку, забезпечення конкурентоспроможності.

Частковий вплив на регулювання параметрів та активізацію інноваційнотехнологічної діяльності в нашій країні мають й інші структури. Це, до прикладу, Державне агентство з енергоефективності та енергозбереження України, Державне агентство інфраструктурних проектів України, Державне космічне агентство України, Державне агентство 3 питань електронного урядування України, Національна комісія, що здійснює державне регулювання у сфері зв'язку та інформатизації. Проте, їх діяльність в більшій мірі функціонально спеціалізована і питання, які виходять за рамки їх компетенцій, навіть такі системні, як інноваційно-технологічний розвиток та конкурентоспроможність національної економіки і пї підприємств, зачасту не ініціюються. Звідси додатковий аргумент на користь важливості функціонування єдиного координуючого державну політику органу.

Але чи не найбільшою вадою в цій структурі слід вважати, власне, відсутність єдиного координуючого органу, відповідального за формування та реалізацію державної політики забезпечення технологічної конкурентоспроможності національної економіки. Потрібно зазначити, що в окремі періоди такі структури були наявні в складі МЕРТ України, але через недоліки у їх функціонуванні, низьку ефективність та ін. причини були ліквідовані (реорганізовані).

Як центральні, так і галузеві та функціональні владні структури мають свої представництва на регіональному та обласному рівнях. Звичайно, що певна діяльність в частині управління та підтримки інноваційно-технологічного розвитку ними ведеться та, як вже було показано, має різну ефективність в різних регіонах країни. Але на регіональному та місцевому рівні наявні інші недоліки. Здебільшого це ресурсна та кадрова обмеженість (що переміщає програми інноваційно-технологічного розвитку на другорядний план в порівнянні 3 більш нагальними соціально-економічними проблемами), низький рівень ініціативності та орієнтованість на виконання завдань «згори», збереження переконання чиновників у тому, що політика технологічної конкурентоспроможності справа бізнесу та не потребує державної підтримки, ін. 
Важливою слід визнати діяльність низки функціонуючих в Україні бізнес-асоціацій та громадських об'єднань, які мають відношення до підтримки науково-технічної, інноваційної та іншої діяльності, пов'язаної зі створенням нових знань, технологій, впровадженням їх результатів у господарську практику. В значній мірі ці структури дозволяють координувати та пов'язувати діяльність різних суб'єктів в рамках інноваційно-технологічної системи, поєднувати суб'єктів бізнесу, орієнтованих на впровадження передових технологій i забезпечення інноваційно-технологічного розвитку компаній, узгоджувати окремі проблемні аспекти на стику відносин влади (зокрема місцевої) і бізнесу, а також різних секторів підприємництва. Але для бізнесасоціацій та громадських структур в Україні ще не створено достатньо сприятливого середовища із їх достатніми повноваженнями. Відтак, здебільшого влада не розглядає такі суб'єкти рівноправним партнером при формуванні та подальшій реалізації інноваційно-технологічної політики, що негативно.

Натомість, ці структури могли б також взяти й більш активну участь у налагодженні співпраці вітчизняних суб'єктів підприємництва 3 міжнародними організаціями в частині залучення (імпорту), інвестування, фінансування, іншої підтримки та сприяння впровадженню на вітчизняних агентах реального сектора економіки сучасних передових технологій.

Відносно інституційно-правової системи державної політики забезпечення технологічної конкурентоспроможності, то їі господарсько-правову частину формують податковий, бюджетний, господарський, цивільний та митний кодекси країни.

Конкретні засади державної політики у сфері інноваційно-технологічної діяльності регулюються основними та допоміжними законами і підзаконними актами держави. Результати аналізу положень дають підстави стверджувати про високий рівень сформованості законодавчого підгрунтя для регулювання ключових основ наукової, науково-технічної, інноваційної, технологічної діяльності, а також таких аспектів 3 ними пов'язаних, як трансфер технологій, науково-технічна інформація, питання охорони та захисту прав на об'єкти інтелектуальної власності, специфіка здійснення інвестиційної та інноваційної діяльності, функціонування інститутів спільного інвестування, реалізація проектів державно-приватного партнерства.

Особливу увагу слід приділити чинній в Україні Загальнодержавній комплексній програмі розвитку високих наукоємних технологій, що була прийнята ще у 2004 р. Програмою були визначені: поняття високих наукоємних технологій, високотехнологічної продукції, високотехнологічного виробництва, проектів 3 розроблення наукоємних технологій; етапи реалізації цілей та завдань програми; очікувані результати, а також конкретні завдання, що мали бути зреалізованими. Але, ці цілі так і не були реалізовані, а часові рамки виконання етапів завершилися ще у 2013 р. Відтак, програмування та планування державної політики забезпечення технологічної конкурентоспроможності економіки України на сьогодні відсутні, що є системним недоліком державної політики в аналізованій сфері. Ці та інші недоліки системи державного регулювання інноваційно-технологічної діяльності, що характерні для України на сучасному етапі розвитку, наведені на рис. 1. 


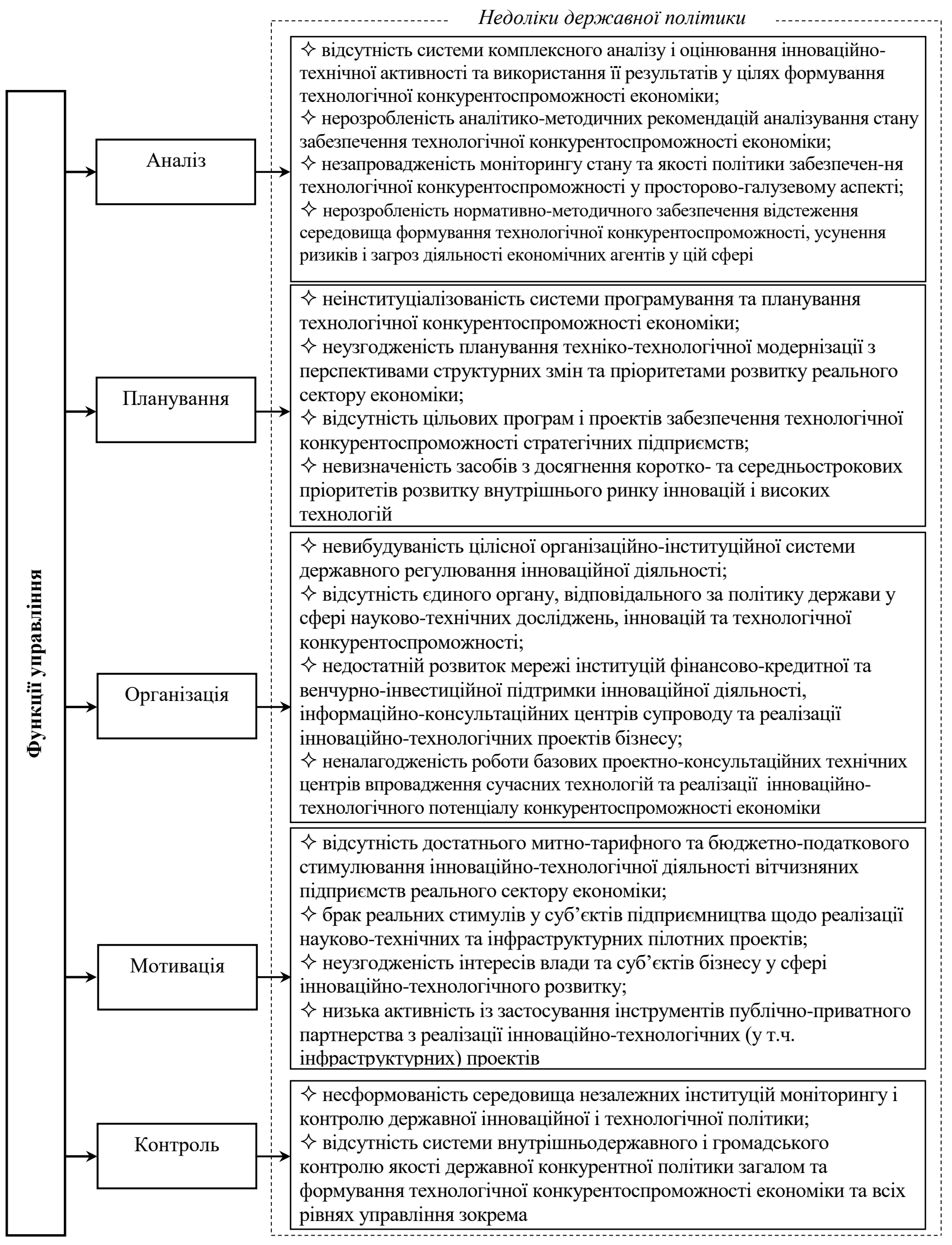

Рис. 1. Результати аналізу ефективності державної політики забезпечення технологічної конкурентоспроможності економіки України за функціями управління 
Наявність аргументів, що доводять існування відповідних вад і прогалин в сфері розвитку інноваційно-технологічної діяльності та забезпечення технологічної конкурентоспроможності економіки, знаходимо не лише на рівні інституційноорганізаційної та інституційно-правової системи державної політики, але й в діяльності підприємств, зокрема стратегічно важливих. В України наявний потенціал і для створення, і для залучення сучасних провідних технологій, що сприятиме зміцненню технологічної конкурентоспроможності вітчизняної економіки. Але, одна 3 умов досягнення цього - удосконалення та суттєве підвищення ефективності вітчизняного регулювання в цій сфері.

Висновки. Недостатній рівень технологічної конкурентоспроможності економіки України в значній мірі обумовлений об'єктивними чинниками, зокрема наявними недоліками в системі державного регулювання процесів інноваційно-технологічної діяльності і розвитку. За результатами аналізування реалізації базисних функцій ідентифіковані наступні недоліки державної політики в цій сфері.

Зокрема, за функцією аналізу це несформованість в країні системи моніторингу i комплексного аналізу інноваційно-технічної активності та використання ії результатів у цілях формування технологічної конкурентоспроможності економіки. Відносно функції планування, то тут базисними недоліками залишаються: неінституціалізованість системи програмування та планування технологічної конкурентоспроможності економіки, відсутність відповідних програм і проектів іiі забезпечення. За функцією організації критично необхідним є подолання таких проблемних аспектів, як відсутність єдиної організаційно-інституційної системи державного регулювання розвитку інноваційнотехнологічної діяльності і забезпечення технологічної конкурентоспроможності економіки. Функція мотивації отримала б значно вищу ефективність в Україні за умови нівелювання таких прорахунків, як недостатність економічно-податкового стимулювання інноваційно-технологічної діяльності вітчизняних підприємств реального сектору економіки, реалізації ними науково-технічних та інфраструктурних пілотних проектів. Визріла необхідність покращення державної політики у сфері забезпечення технологічної конкурентоспроможності економіки й за функцією контролю.

Подальші дослідження в цьому напрямі мають стосуватися формування методики оцінювання державної політики забезпечення технологічної конкурентоспроможності.

\section{Список біблографічного опису:}

1. Антонюк Л. Л. Міжнародна конкурентоспроможність країн: теорія та механізм реалізації : монографія. Київ : Вектор, 2004.273 с. 2. Васильців Т. Г. Формування середовища економічної безпеки підприємництва в Україні. Економічний часопис-XXI. 2015. № 3-4 (1). С. $24-27$.

3. Геєць В. Інститути у розширенні технологічної модернізації економіки України. Журнал європейської економіки. 2016. Т. 15 (3). С. $255-265$.

4.Піддубна Л. І. Конкурентоспроможність економічних систем: теорія, механізм регулювання та управління : монографія. Харків : ВД “ІНЖЕК”, 2007. 368 с.

5. Тараненко I. В. Алгоритм дослідження та оцінки інноваційної конкурентоспроможності країн. Науковий вісник Уљсгородського університету. Економіка. 2011. Вип. 33, Ч. 1. С. 196-201.

6. Федулова Л. І. Концептуальна модель інноваційної стратегії України. Економіка і прогнозування. 2012. № 1. С. 87-100.

7. Швиданенко О. А. Глобальна парадигма конкурентоспроможності: імперативи становлення та розвитку : дис... д-ра екон. наук. Київ, 2007. 523 с.

8. Юринець 3. В. Інноваційні стратегії в системі підвищення конкурентоспроможності економіки України : дис. ... д-ра екон. наук. Львів, 2016. $519 \mathrm{c}$.

9. Vasyltsiv T., Lupak R., Osadchuck Yu. Assessement of the level of penetration of import dependence in the context of the import substitution policy in Ukraine. Економічний часопис-XXI. 2017. № 167 (9-10). C. 13-17.

10. Лупак Р. Л. Державна політика імпортозаміщення в системі забезпечення економічної безпеки України: пріоритети та інструменти реалізації : монографія. Львів : Вид-во ННВК «АТБ», 2018. 527 с.

\section{References}

1. Antonyuk L. L. (2004) Mizhnarodna konkurentospromozhnist' krayin: teoriya ta mekhanizm realizatsiyi [International Competitiveness of Countries: Theory and Mechanism of Realization]. Kyiv: Vektor. [in Ukrainian]

2. Vasyl'tsiv T. H. (2015). Formuvannya seredovyshcha ekonomichnoyi bezpeky pidpryyemnytstva $v$ Ukrayini [Formation of the environment of economic security of entrepreneurship in Ukraine]. Ekonomichnyy chasopys-XXI, 3-4(1), 24-27. [in Ukrainian]

3. Heyets' V. (2016). Instytuty u rozshyrenni tekhnolohichnoyi modernizatsiyi ekonomiky Ukrayiny [Institutes in the expansion of technological modernization of the Ukrainian economy]. Zhurnal yevropeys'koyi ekonomiky, 15 (3), 255-265. [in Ukrainian]

4. Piddubna L. I. (2007). Konkurentospromozhnist' ekonomichnykh system: teoriya, mekhanizm rehulyuvannya ta upravlinnya [Competitiveness of economic systems: theory, mechanism of regulation and management]. Xarkov: VD "INZHEK". [in Ukrainian]

5. Taranenko I. V. (2011). Alhorytm doslidzhennya ta otsinky innovatsiynoyi konkurentospromozhnosti krayin [Algorithm of research and estimation of innovative competitiveness of countries]. Naukovyy visnyk Uzhhorods'koho universytetu. Ekonomika, 33 (1), 196-201. [in Ukrainian]

6. Fedulova L. I. (2012). Kontseptual'na model' innovatsiynoyi stratehiyi Ukrayiny [Conceptual model of innovation strategy of Ukraine]. 
Ekonomika i prohnozuvannya, 1, 87-100. [in Ukrainian]

7. Shvydanenko O. A. (2007). Hlobal'na paradyhma konkurentospromozhnosti: imperatyvy stanovlennya ta rozvytku [The Global Competitiveness Paradigm: Imperatives of Development and Development] (PhD Thesis), Kyiv: Kyiv National Economic University Vadim Hetman.

8. Yurynets' Z. V. (2016). Innovatsiyni stratehiyi v systemi pidvyshchennya konkurentospromozhnosti ekonomiky Ukrayiny [Innovative Strategies in the System of Increasing the Competitiveness of the Ukrainian Economy] PhD Thesis), Lviv: Lviv National University Ivan Franko.

9. Vasyltsiv T., Lupak R., Osadchuck Yu. (2017). Assessement of the level of penetration of import dependence in the context of the import substitution policy in Ukraine. Ekonomichnyy chasopys-XXI, 167 (9-10), 13-17. [in English]

10. Lupak R. L. (2018). Derzhavna polityka importozamishchennya v systemi zabezpechennya ekonomichnoyi bezpeky Ukrayiny: priorytety ta instrumenty realizatsiyi [State policy of import substitution in the system of economic security of Ukraine: priorities and implementation tools]. Lviv : NNVK «ATB». [in Ukrainian].

Рецеензент д.е.н., професор Васильијі Т.Г.

УДК 336:334.012.64

Матвійчук Л.Ю., д.е.н., професор

Луцький національний технічний університет

\section{ШЛЯХИ ПІДВИЩЕННЯ ЯКОСТІ СИСТЕМИ НАДАННЯ ПОСЛУГ САLL-ЦЕНТРАМИ}

Розглянуто принципи та сучасні підходи до визначення якості надання послуг call-центрами, проаналізовано основні аспекти їх роботи. Проведено аналіз понятійно-термінологічного апарату на основі чого визначено основні характерні ознаки якості послуг. Систематизовано загальні показники виміру якості надання послуг call-центрами енергетичної галузі. Визначено основні напрями підвищення якості функціонування call-центрів. До них віднесено: проведення державного моніторингу процесу надання послуг та оцінювання якості послуг за спеціально встановленими методиками; затвердження державних стандартів якості надання послуг; забезпечення отримання послуг багатьма мовами; періодичне навчання операторів call-центрів та створення умов для постійного обміну досвідом; активне залучення громадськості до процесу оцінки якості послуг, що надаються, та повна прозорість їх надання; наявність ефективної системи оскарження дій суб'єкта надання послуги; активний розвиток системи надання електронних послуг.

Ключові слова: система послуг, показники якості, робота call-центрів.

Matviychuk L.

\section{WAYS TO IMPROVE SERVICE SYSTEM QUALITY CALL-CENTERS}

The principles and modern approaches to defining the quality of call-center services are considered; the main aspects of their work are analyzed. The analysis of the conceptual terminology apparatus is carried out on the basis of which the main characteristic features of quality of services are determined. The general indicators for measuring the quality of service delivery in the energy industry call-centers have been systematized. The main directions of improving the quality of functioning of call centers are determined. These include: conducting state monitoring of the process of providing services and assessing the quality of services using specially established methods; approval of state quality standards for service delivery; providing services in many languages; periodic training of call-center operators and creation of conditions for continuous exchange of experience; active involvement of the public in the process of evaluating the quality of services provided and full transparency of their provision; the existence of an effective system for challenging the actions of the entity providing the service; active development of the electronic services delivery system.

Keywords: service system, quality indicators, operation of call-centers.

Матвийчук Л.Ю.

\section{ПУТИ ПОВЫШЕНИЯ КАЧЕСТВА СИСТЕМЫ ПРЕДОСТАВЛЕНИЯ УСЛУГ САLL-ЦЕНТРАМИ}

Рассмотрены принципы и современные подходы к определению качества предоставления услуг callцентрами, проанализированы основные аспекты их работы. Проведен анализ понятийнотерминологического аппарата на основе чего определены основные характерные признаки качества услуг. Систематизированы общие показатели измерения качества предоставления услуг сall-центрами 